\title{
Clinical Observations Group Identifier
}

National Cancer Institute

\section{Source}

National Cancer Institute. Clinical Observations Group Identifier. NCI Thesaurus. Code C119803.

A character or string that represents a clinical observation findings group. 